3 Zipursky A, Palko J, Milner R, Akenzua G I. The hematology of bacterial infections in premature infants. Pediatrics 1976; 57: 839-53.

4 Manroe B L, Rosenfeld C R, Weinberg A G, Browne R. The differential leukocyte count in the assessment and outcome of early onset neonatal group B streptococcal disease. J Pediatr 1977; 91 : 632-7.

5 Xanthou M. Leucocyte blood picture in healthy full term and premature babies during neonatal period. Arch Dis Child 1970; 45: 242-9.

6 Manroe B L, Weinberg A G, Rosenfeld C R, Browne R. The neonatal blood count in health and disease. I. Reference values for neutrophilic cells. J Pediatr 1979; 95: 89-98.
7 Coulombel L, Dehan M, Tchernia G, Hill C, Vial M. The number of polymorphonuclear leukocytes in relation to gestational age in the newborn. Acta Paediatr Scand 1979; 68: 709-11.

8 Dubowitz L M S, Dubowitz V, Goldberg C. Clinical assessment of gestational age in the newborn infant. J Pediatr 1970; 77: 1-10.

Correspondence to Dr B W Lloyd, Department of Paediatrics, New Cross Hospital. Wolverhampton WV10 OQP.

Received 17 November 1981

\title{
Oral converting enzyme inhibitor in malignant hypertension
}

\author{
WILLIAM GRISWOLD, RICHARD MCNEAL, DAN O'CONNOR, VIVIAN REZNIK, AND \\ STANLEY MENDOZA
}

Department of Pediatrics, University of California, San Diego, USA

SUMMARY Malignant hypertension, which developed in a 9-year-old boy after an episode of haemolytic uraemic syndrome, could not be controlled with antihypertensive agents. However, treatment with oral converting enzyme inhibitor (captopril) was effective in controlling the blood pressure and it averted bilateral nephrectomy. No adverse effects from the drug were noted.

Captopril (SQ 14225), an orally active inhibitor of angiotensin converting enzyme, has been used for the control of hypertension in adults. The following case shows the striking effectiveness of captopril in a child with malignant, high renin, drug-resistant hypertension.

\section{Case report}

This 9-year-old boy had been in good health until December 1977 when he developed haemolytic uraemic syndrome. In the hospital, the patient was anuric for $\mathbf{1 7}$ days and required peritoneal dialysis. As urine output resumed the blood pressure increased to $150 / 100 \mathrm{mmHg}$ requiring antihypertensive therapy. The patient was discharged after one month with a serum creatinine concentration of $1.6 \mathrm{mg} / 100$ $\mathrm{ml}(142 \mu \mathrm{mol} / \mathrm{l})$.

However one month later blood pressure rose to $150 / 110 \mathrm{mmHg}$ and the patient was readmitted with papilloedema, plasma urea $29 \mathrm{mmol} / \mathrm{l}$, and creatinine $4.4 \mathrm{mg} / 100 \mathrm{ml}(392 \mu \mathrm{mol} / \mathrm{l})$. Despite treatment the blood pressure was poorly controlled and serum creatinine levels remained high. Urinary vanillylmandelic acid was normal. Intravenous pyelogram and technetium renal scan showed decreased renal function but were otherwise normal. Peripheral venous renin was greatly increased at over $100 \mathrm{ng} / \mathrm{ml}$ per hour (normal 0-5). Renal biopsy showed evidence of nephrosclerosis with severe endothelial proliferation in the arterioles. Bilateral selective renal angiograms showed loss of corticomedullary junction and interlobular arteries suggesting glomerular disease. Renin was 81.9 in the right renal vein and $111 \mathrm{ng} / \mathrm{ml}$ per hour in the left.

His subsequent course was difficult, complicated by persistent hypertension despite treatment with various combinations of the following; propranolol $480 \mathrm{mg} /$ day $(26 \mathrm{mg} / \mathrm{kg}$ per day), hydralazine 400 $\mathrm{mg} /$ day (22 $\mathrm{mg} / \mathrm{kg}$ per day), prazosin $12 \mathrm{mg} /$ day $(0.6 \mathrm{mg} / \mathrm{kg}$ per day), methyldopa $1500 \mathrm{mg} /$ day $(82 \mathrm{mg} / \mathrm{kg}$ per day), clonidine $0.8 \mathrm{mg} /$ day $(0.04$ $\mathrm{mg} / \mathrm{kg}$ per day), minoxidil $40 \mathrm{mg} /$ day $(2.2 \mathrm{mg} / \mathrm{kg}$ per day), guanethidine $100 \mathrm{mg} /$ day $(5.5 \mathrm{mg} / \mathrm{kg}$ per day), and frusemide $400 \mathrm{mg} /$ day $(22 \mathrm{mg} / \mathrm{kg}$ per day). Heart size was persistently enlarged on chest $x$-ray film; echocardiogram showed left ventricular hypertrophy and pericardial effusion. Weight decreased to $18 \cdot 2 \mathrm{~kg}$. He was depressed and anorectic. There were 2 episodes of hypertensive encephalopathy. He underwent pericardiectomy for treatment of persistent effusion, probably due to minoxidil, in September 1978.

In late December 1978, permission to use captopril for this patient was obtained from Squibb via a humanitarian protocol. Other antihypertensives were 
stopped in the morning and the patient was given $6 \mathrm{mg}$ of captopril $(0.03 \mathrm{mg} / \mathrm{kg}$ per dose). Before captopril the blood pressure was $140 / 110 \mathrm{mmHg}$. Twenty minutes later it had fallen to $88 / 70 \mathrm{mmHg}$ and a dopamine drip was started. The patient suffered no ill effects from the hypotension.

During the next few days small doses of 1-2 mg $(0.05-0.1) \mathrm{mg} / \mathrm{kg}$ of captopril were found to reduce the blood pressure for 3-31 hours if the pressure had again risen and was causing difficulty in titration of the drug. After 3 weeks the wide fluctuations in pressure ceased and blood pressure control was satisfactory.

In January 1979 the patient developed hypercalcaemia. Parathormone was not detectable at serum calcium of $12-14 \mathrm{mg} / 100 \mathrm{ml}(3-3.5 \mathrm{mmol} / \mathrm{l})$. A diagnosis of immobilisation hypercalcaemia was made and the patient was treated with a high salt diet and frusemide. This regimen did not affect the blood pressure adversely and serum calcium fell to normal levels.

Now 24 months after the first dose the patient is doing well on captopril $25 \mathrm{mg}$ three times daily $(1.9 \mathrm{mg} / \mathrm{kg}$ per day) and frusemide $20 \mathrm{mg}$ twice daily $(1 \mathrm{mg} / \mathrm{kg}$ per day). Blood pressure averages $118 / 70 \mathrm{mmHg}$. Weight has increased to $40 \mathrm{~kg}$, serum creatinine concentration is $1.2 \mathrm{mg} / 100$ $\mathrm{ml}(107 \mu \mathrm{mol} / \mathrm{l})$, 24-hour urine protein is normal, and plasma renin activity is $33 \mathrm{ng} / \mathrm{ml}$ per hour (normal 0-5) (Table). Chest $x$-ray film shows a normal cardiac silhouette; electrocardiogram is normal.

A mild hepatitis has persisted throughout the patient's illness. Liver biopsies obtained 1 and 9 months after captopril were similar, each showing mild periportal inflammation without evidence of hepatic destruction.

\section{Discussion}

Inhibitors of the renin-angiotensin system became available for clinical research in the early 1970s. The two main agents were saralasin, a competitive antagonist of angiotensin II, and teprotide (SQ 20881), an inhibitor of the enzyme converting angiotensin I to angiotensin II. Each of these agents has the disadvantage of requiring parenteral administration. Use in children has been limited. ${ }^{1}$ An orally active inhibitor of the angiotensin converting enzyme has recently been developed. ${ }^{2}$ It has had successful clinical application in several series of hypertensive adults. ${ }^{3-6}$ Use of this agent has been reported in only one child.

The mechanism of the antihypertensive effect of captopril may be in its ability to decrease production of the pressor angiotensin II and to increase production of the vasodilator bradykinin. ${ }^{3}$ Other mechanisms may also play a role. ${ }^{6}$ Although the effectiveness of captopril did not correlate with pretreatment renin levels in adults, its antihypertensive effect was more pronounced in patients with renovascular or malignant hypertension. This may indicate the reason for its effectiveness in our patient. The striking hypotensive response to an initial low dose of captopril in our patient should suggest caution in initiating similar treatment in children.

Our patient had malignant hypertension after what appeared to be an episode of haemolytic uraemic syndrome. He had severe sequelae both from hypertension and its management. Use of captopril averted bilateral nephrectomy. The use of captopril simplified his medication regimen from 10 medications to two. He has suffered no side effects and there has been a great improvement in his mental and physical condition. Captopril may prove to be a

Table Details before and during treatment with captopril

\begin{tabular}{|c|c|c|c|c|c|}
\hline & \multicolumn{2}{|l|}{ Before captopril } & \multicolumn{3}{|c|}{ During captopril in 1979} \\
\hline & December 1977 & November 1978 & February & May & November \\
\hline Blood pressure & $150 / 100$ & $150 / 100$ & $120 / 85$ & $120 / 80$ & $130 / 84$ \\
\hline Weight (kg) & 26 & $18 \cdot 2$ & 21 & 26 & $30 \cdot 9$ \\
\hline Plasma urea (mg/100 ml) & 91 & 105 & 69 & 30 & 37 \\
\hline Creatinine $(\mathrm{mg} / 100 \mathrm{ml})$ & $2 \cdot 1$ & $3 \cdot 0-5 \cdot 1$ & $1 \cdot 2$ & $1 \cdot 1$ & $1 \cdot 1$ \\
\hline Renin (ng/ml per hour)* & ND & $19 \cdot 2$ & ND & 33 & ND \\
\hline Plasma aldosterone $(\mathrm{pg} / \mathrm{ml}) \dagger$ & ND & 1037 & ND & 75 & ND \\
\hline AST (IU/1) & 200 & 156 & ND & 234 & 228 \\
\hline Glutamic-oxaloacetic transaminase (IU/1) & ND & 89 & ND & 287 & 296 \\
\hline \multicolumn{6}{|l|}{ Bilirubin (mg/100 ml) } \\
\hline Total & $1 \cdot 5$ & $1 \cdot 8$ & ND & $0 \cdot 2$ & 0.4 \\
\hline Direct & ND & $\mathbf{0} \cdot \mathbf{3}$ & ND & $0 \cdot 1$ & 0.3 \\
\hline 24-hour urine protein ( $\mathrm{g} / 24$ hour) & ND & $1 \cdot 1$ & ND & 0.202 & 0.009 \\
\hline Creatinine clearance $\left(\mathrm{ml} / \mathrm{min}\right.$ per $\left.1.73 \mathrm{~m}^{2}\right)$ & ND & 22 & ND & 33 & 46 \\
\hline
\end{tabular}

* Normal 0-5 ng/ml per hour, tnormal 13-114 pg/ml.

ND = not done.

Conversion: traditional units to $S I$ : Plasma urea $1 \mathrm{mg} / 100 \mathrm{ml} \approx 0.357 \mathrm{mmol} / 1$, creatinine $1 \mathrm{mg} / 100 \mathrm{ml} \approx 89 \mathrm{mmol} / 1, \mathrm{bilirubin} 1 \mathrm{mg} / 100 \mathrm{mg} \approx$ 17. $1 \mathrm{\mu mol} / 1$. 
useful agent in the management of other children with severe hypertension who are nonresponsive to the usual medical management.

Two important changes in the renin-angiotensin system were observed after treatment with captopril. Captopril lowered plasma aldosterone by blocking the production of angiotensin II, a known stimulator of adrenal aldosterone production. Captopril also increased plasma renin levels, presumably by interrupting the negative feedback loop which controls renin secretion.

Improved creatinine clearance after captopril, which was seen in our patient, has been reported in adults. ${ }^{5}$ The cause of this change is unknown, but renal vasodilatation, decrease in nephrosclerosis, and resolution of the haemolytic syndrome may each have played a role in the patient reported here.

Captopril has several apparent advantages over minoxidil, another agent useful in severe hypertension. ${ }^{7}$ Minoxidil causes pronounced sodium retention which must be aggressively managed with dietary sodium restriction and diuretics. While receiving captopril and frusemide our patient was able to tolerate a high salt diet for treatment of immobilisation hypercalcaemia without adverse effects on blood pressure. The ability to tolerate salt results, in part, from lowered aldosterone levels. The hirsutism caused by minoxidil has limited its usefulness in children.

This patient has had hepatitis throughout the illness. The aetiology of the hepatitis is unknown. The possibility that our patient had an exacerbation of hepatitis due to captopril cannot be completely excluded. However, according to the Squibb monitor, hepatotoxicity has not been observed in other patients receiving captopril.

Captopril was supplied by Squibb under a humanitarian protocol.

\section{References}

1 Trainin E B, Lala V R, Gomez-Leon G, AvRuskin T W. Negative saralasin response in correctable renovascular hypertension. J Pediatr 1978; 93: 460-2.

2 Ondetti M A, Rubin B, Cushman D W. Design of specific inhibitors of angiotensin-converting enzyme. New class of orally active antihypertensive agents. Science 1977; 196: $441-4$.

3 Brunner $\mathrm{H}$ R, Gavras H, Waeber B, et al. Oral angiotensin-converting enzyme inhibitor in long-term treatment of hypertensive patients. Ann Intern Med 1979; 90: 19-23.

- 4 Ferguson R K, Brunner H R, Turini G A, Gavras H, McKinstry D N. A specific orally active inhibitor of angiotensin-converting enzyme in man. Lancet 1977; i: $775-8$.

5 Hollenberg N K, Swartz S L, Passan D P, Williams G H. Increased glomerular filtration rate after converting enzyme inhibition in essential hypertension. $N$ Engl $J$ Med $1979 ; 301$ : 9-12.

6 Gavras H, Brunner H R, Turini G A, et al. Antihypertensive effect of the oral angiotensin converting-enzyme inhibitor SQ 14225 in man. $N$ Engl $J$ Med 1978; 298: 991-5.

7 Peltinger W A, Mitchell H C. Minoxidil-an alternative to nephrectomy for refractory hypertension. $N$ Engl $J$ Med 1973; 289: 167-71.

Correspondence to Dr W R Griswold, University Hospital, Pediatric Nephrology (H 814 E), 225 W Dickinson Street, San Diego, California 92103, USA.

Received 5 October 1981

\section{Oxygen embolus during mechanical ventilation with disappearance of signs after death}

\section{P T RUDD AND J S WIGGLESWORTH}

\section{Department of Paediatrics and Neonatal Medicine, Hammersmith Hospital, London}

SUMMARY Oxygen embolus is thought to be a rare complication of mechanical ventilation in preterm infants. In the patient described there was clinical and radiological evidence of embolisation within the heart and great vessels, but at necropsy gas was seen only in the cerebral arteries.

\section{Case report}

This boy (birthweight $900 \mathrm{~g}$ ) was the second of undiagnosed twins delivered by lower segment caesarean section from a woman with severe preeclampsia at 29 weeks' gestation. He was transferred to this hospital at 4 hours, receiving artificial ventilation because of idiopathic respiratory distress syndrome (LS ratio $1 \cdot 5: 1)$. Despite ventilation at low peak pressure $(14 / 2 \mathrm{~cm}$ of water) he developed pulmonary interstitial emphysema followed by a pneumothorax at 26 hours. A chest drain was inserted but he became acidotic and hypoxic, responding to high rates of ventilation as well as to buffer and 